\title{
Complete mitochondrial genome of Cultellus attenuatus and its phylogenetic implications
}

\author{
Haikun Li ( $\boldsymbol{D} 1157474258 @ q q . c o m$ ) \\ Ocean University of China Fisheries College \\ Ruihai Yu \\ Ocean University of China Fisheries College \\ Peizhen Ma \\ Institute of Oceanology Chinese Academy of Sciences \\ Chunhua Li \\ Ocean University of China Fisheries College
}

\section{Short Report}

Keywords: Cultellus attenuates, M itochondrial gene, Phylogeny, Heterodonta

Posted Date: September 3rd, 2021

DOI: https://doi.org/10.21203/rs.3.rs-868770/v1

License: (9) This work is licensed under a Creative Commons Attribution 4.0 International License. Read Full License 
Complete mitochondrial genome of Cultellus attenuatus and its phylogenetic implications

1 Haikun $\mathrm{Li}^{1}$, Ruihai $\mathrm{Yu}^{1}$, Peizhen $\mathrm{Ma}^{2}$, Chunhua $\mathrm{Li}^{1}$

$2 \quad{ }^{1}$ Key Laboratory of Mariculture, Ministry of Education, Ocean University

3 of China, 5 Yushan Road, Qingdao 266003, China

$4 \quad{ }^{2}$ Institute of Oceanology, Chinese Academy of Sciences, 7 Nanhai Road,

$5 \quad$ Qingdao 266071, China

6 Corresponding author

7 Ruihai Yu, Key Laboratory of Mariculture, Ministry of Education, Ocean

8 University of China, Qingdao 266003, China.

9 Email: yuruihai@ouc.edu.cn

\section{Acknowledgments}

11 This work was supported by the grants from National Natural Science

12 Foundation of China (31172403), Science and Technology Innovation

13 Commission Project of Shenzhen, China (CXY201106270024A). 


\section{Abstract}

The complete mitochondrial genome of Cultellus attenuates, a new aquaculture species, was sequenced and compared with mitogenomes from seven species of Heterodonta bivalve mollusk in the gene bank. The mitochondrial genome of $C$. attenuatus is $16888 \mathrm{bp}$ in length and contains 36 genes, including 12 protein-coding genes, 2 ribosomal RNAs and 22 transfer RNAs, and all genes are encoded on the same strand. In comparison with $C$. attenuates, the mitochondrial genes of the Sinonovacula constricta from the same family were not rearranged, but those of six other species from different family were rearranged to different degrees. The largest non-coding region of $C$. attenuatus is $1173 \mathrm{bp}$ in length and with the A $+\mathrm{T}$ content of $68.24 \%$, located between nad2 and trnK. The results of phylogenetic analysis show that the $C$. attenuates and the $S$. constricta belonging to Cultellidae cluster into one branch while two species of Solenidae (Solen grandis and Solen strictus) are clustering as their sister taxon. These data not only contribute to the understanding of the phylogenetic relationship of the Heterodonta, but also serve as a resource for the development of the genetic markers in aquaculture.

Keywords Cultellus attenuates · Mitochondrial gene · Phylogeny ·

Heterodonta 


\section{Introduction}

Most animals' mitochondrial DNA is a closed circular molecule independent of the nuclear DNA, ranging in size from 14 to $17 \mathrm{~kb}$. It contains 37 genes including 13 proteins, 2 ribosomal RNAs, and 22 transfer RNAs ${ }^{[1]}$.The mitochondrial genes are quite conservative in replication, featuring matrilineal inheritance, no rearrangement and high substitution rates ${ }^{[2]}$. Many characteristics make mitochondrial genes in value and have has become a powerful source in genetic evolution, phylogeographic analysis, and species identification ${ }^{[3-5]}$.

In bivalve mollusk, Mytilus edulis was the first to obtain complete mitochondrial genetic information ${ }^{[6]}$, and subsequently mitochondrial genes were obtained in other categories, including oysters ${ }^{[7]}$, scallops ${ }^{[8]}$, $\operatorname{clam}^{[9]}$ and razor shells ${ }^{[10]}$. Although mitochondrial genetic resources of bivalve are increasingly being developed, it is only limited to some species with high economic value. For niche classes, the molecular information is scarce ${ }^{[11]}$. In the species of Cultellidae family, only the mitochondrial genes of Sinonovacula constricta have been determined while those of the other species including Cultellus attenuatus have been not, which has been very unfavorable for the phylogenetic research in this family ${ }^{[12,13]}$.

C. attenuatus mainly inhabits the shallow sea area of the subtidal zones, and can be found in Japan, South Korea, the Philippines and in China 
57 (mainly from Liaoning in the north to Taiwan in the south) ${ }^{[14]}$. C. attenuatus has high edible value due to its nutritional composition of low fat and high protein, which makes it more and more popular among Chinese consumers ${ }^{[15]}$. In this way, the high market value of $C$. attenuatus has makes its artificial catching gradually increase while, the quantity of wild resources ones decrease ${ }^{[14]}$. In china, artificial breeding of $C$. attenuatus has been carried out in an attempt to restore the diminishing wild resources by introducing hatchery-produced seed. The study of mitochondrial gene can be applied to produce genetic markers that can monitor the restoration of aquatic animal stock, which is quite helpful for the restoration and conservation of wild population ${ }^{[3,16-17]}$. Therefore, it is necessary to obtain the mitochondrial gene sequence of $C$. attenuates. However, no relevant reports have been reported so far. In this study, we obtained and analyzed the entire mitochondrial gene of $C$. attenuates, and compared the mitochondrial gene with other family species from the Heterodonta. The data not only contribute to our understanding of the phylogenetic status, but also serve as a source for the development of useful genetic markers in aquaculture.

\section{Materials and methods}

\section{Sample collection and DNA extraction}


The lived C. attenuatus were collected from Bohai Bay (Dongying City, Shandong Province, China). The total genomic DNA was extracted from adductor muscle of an individual C. attenuatus by a DNA extraction kit.

\section{PCR and DNA sequencing}

The PCR amplification of cox 1 and $\operatorname{rrnL}$ gene was performed with the primer set of LCO1490/HCO2198 and rrnLAR-L/rrnLAR-H ${ }^{[13]}$, respectively. PCR was performed in $50 \mu \mathrm{l}$ volumes containing 0.5 units Taq polymerase (Takara), $1 \times$ PCR buffer, $0.2 \mathrm{mM}$ of each dNTP, $1 \mu \mathrm{M}$ of each primer, $1.5 \mathrm{mM}$ of $\mathrm{MgCl}_{2}$ and50 ng of genomic DNA. The PCR cycle was as follows: $94^{\circ} \mathrm{C}$ for $2 \mathrm{~min}$, then 35 cycles of $94^{\circ} \mathrm{C}$ for $30 \mathrm{~s}, 40 \mathrm{~s}$ at $52^{\circ} \mathrm{C}$ and $1 \mathrm{~min}$ at $72^{\circ} \mathrm{C}$, followed by a final extension at $72^{\circ} \mathrm{C}$ for 5 $\min$.

Based on the above two sequences, two sets of Long-PCR primers LB-L/ LB-H and LC-L/LC-L were used for long-PCR amplification ${ }^{[13]}$. Long-PCR was performed in $25 \mu \mathrm{L}$ volumes containing $1 \times \mathrm{GC}$ buffer $\mathrm{I}$, 1.25 $\mathrm{U}$ of LATaq (Takara), $0.5 \mathrm{mM}$ of each dNTP, $0.4 \mu \mathrm{M}$ of each primer and $50 \mathrm{ng}$ of genomic DNA. The PCR conditions were as follows: $94^{\circ} \mathrm{C}$ for $2 \mathrm{~min}, 30$ cycles of $94^{\circ} \mathrm{C}$ for $20 \mathrm{~s}, 1 \mathrm{~min} / \mathrm{kb}$ at $68^{\circ} \mathrm{C}$ and a final extension at $72^{\circ} \mathrm{C}$ for $10 \mathrm{~min}$. The PCR products were sequenced by Personal Biotechnology Co. Ltd. Qingdao.

\section{Analysis of sequence data}


99 similarity to published gene sequences through BLAST searches 100 (http://www.ncbi.nlm.nih.gov/BLAST/). The transfer RNA were 101 identified by tRNAscan-SE v.1.21 ${ }^{[18]}$ and DOGMA ${ }^{[19]}$ using invertebrate 102 mitochondrial genetic code. CGView was used to map the whole 103 mitochondrial genome circle ${ }^{[20]}$.

The protein-coding and ribosomal RNA genes were identified by their Phylogenetic analysis

To clearly show the phylogenetic relationship of the Heterodonta, the mitochondrial gene sequences of 18 species from the Heterodonta were obtained from the gene bank. The Chlamys farreri and Mimachlamys nobilis were used as distinct outgroups. The amino acid sequences of 12 proteins (except atp8) were adopted for phylogenetic analysis. The amino acid sequences of 12 mitochondrial proteins were aligned by MEAG 7.0. [21]. The phylogenetic relationships of heterodont bivalves were reconstructed by the Neighbor-Joining (NJ), and 1000 bootstraps were used to estimate.

\section{Results and discussion}

\section{Genome organization and nucleotide composition}

The mitochondrial genome of $C$. attenuates is 16,888 bp in length and contains 12 protein-coding genes, 22 transfer RNA genes, and 2 ribosomal RNA genes (Fig. 1). Compared with the genome size of the 
sequenced mollusk mtDNAs, the mitochondrial genome size is within the normal range. Besides, four overlaps were detected in mitochondrial genome, with the size of $1 \mathrm{bp}, 6 \mathrm{bp}, 1 \mathrm{bp}$ and $3 \mathrm{bp}$ respectively, among which the overlap between trnE and trnS2 was the largest (Table 1). Of the whole mitogenome of $C$. attenuates, its $\mathrm{A}+\mathrm{T}$ content is $66.46 \%$ (Table 2), comparable to that of S. constricta $(67.00 \%)$ and Solen grandis (64.84\%). In addition, the mitochondrial gene length of $C$. attenuates is $376 \mathrm{bp}$ shorter than that of $S$. constricta in the same family ${ }^{[22]}$, while 104bp longer than that of $S$. grandis in the different family ${ }^{[10]}$.

\section{Protein-coding genes and codon usage}

The mitochondria of $C$. attenuates contain 12 protein-coding genes, which, range in size from $291 \mathrm{bp}$ to $1761 \mathrm{bp}$ and, with a total length of $11470 \mathrm{bp}$, accounting for $67.92 \%$ of the total length of the genes (Table 1). There are two starting codons in these 12 protein-coding genes, ATG for 7 protein-coding genes (cox2, cox3, cob, atp6, nad2, nad3 and nad6), ATT for 3 protein-coding genes (cox1, nad4 and nad5) and ATA for 2 protein-coding genes (nad41 and nad1), which differs from the initial codon composition of the protein-coding genes in mtDNA of $S$. grandis. Except for cox2, all the other 11 protein-coding genes have complete termination codons, including TAA $(\mathrm{N}=5)$ and TAG $(\mathrm{N}=6)$. The $\mathrm{A}+\mathrm{T}$ content of all the protein-coding genes exceeds $60 \%$, indicating that the protein-coding genes prefer AT. 
142 of the entire mitochondrial genome are -0.291 and 0.368 , respectively, 143 suggesting that the entire mitochondrial gene is biased towards $\mathrm{T}$ and $\mathrm{G}, \mathrm{a}$ 144 phenomenon also found in some other bivalves ${ }^{[7-8,23]}$. All the 12 145 146 skew and positive GT skew, showing a bias towards T and G (Table 2).

Of the entire mitochondrial genome, the values of AT skew and GT skew protein-coding genes are similar to the whole genome, with negative AT

\section{Ribosomal RNAs and transfer RNAs}

Similar to most bivalves, the mitochondrial genomes of $C$. attenuates contain 22 transfer RNA genes and 2 ribosomal RNA genes. The size of 22 tRNA genes varies from $63 \mathrm{bp}$ to $67 \mathrm{bp}$, and all of them can be folded into typical secondary structures. The two ribosomal RNA genes include rrnL and $\mathrm{rnS}$ - the former is $1237 \mathrm{bp}$, located between nad6 and atp6, and the latter is $827 \mathrm{bp}$ located between trnM and cox3 (Table 1). The content of $\mathrm{A}+\mathrm{T}$ in $\mathrm{rrnL}$ is $69.68 \%$, which is the highest in all protein coding genes and rRNA genes. The A+T content of $\mathrm{rrnS}$ is $66.38 \%$, which is slightly lower than the average level of the whole mitochondrial genome. The contents of AT skew and GC skew of rnL are -0.063 and 0.285 respectively, which is similar to the protein coding gene and has a bias towards $\mathrm{T}$ and $\mathrm{G}$. The contents of AT skew and GC skew of rrnS are 0.056 and 0.209 respectively, showing a bias towards A and G, which is different from other genes in the whole mitochondrial genes (Table 2). 
162

163

164

165

166

\section{Non-coding regions}

The mitochondrial genome of the whole $C$. attenuates contains 24 non-coding regions, ranging in size from $2 b p-1173 b p$, with a total length of totaling $1917 \mathrm{bp}$, accounting for $11.35 \%$ of the entire mitochondrial genome. 4 of the 24 non-coding regions are larger, with the size greater than or equal to $100 \mathrm{bp}$, which are respectively 103bp (trnP-nad4), 149bp (trnF-cox1), 100bp (trnM-rrnS) and 1173bp (nad2-trnK). The largest non-coding region (NCR) is $1173 \mathrm{bp}$ in length and with the $\mathrm{A}+\mathrm{T}$ content of $68.24 \%$, located between nad 2 and trnK. Besides, in the largest NCR, a sequence (15884bp -15974bp) with low A+T content (53.85\%) was found, which is considered to be the origin of L-strand replication. The remaining sequence of the largest NCR is 914 bp in length, with an AT content of $69.80 \%$, and is identified as a putative control region. Compared with the largest NCR of the $C$. attenuates, the largest NCR of S. constricta in the same family is at the same position $(\operatorname{nad} 2-\operatorname{trnK})$ with slightly larger size $(1492 \mathrm{bp})$ and lower $\mathrm{A}+\mathrm{T}$ content $(66.89 \%)^{[22]}$. The largest NCR positions and sizes of $C$. attenuates varied considerably compared with other 6 species of different families (Table 3), indicating the highly rearranged gene order in bivalves.

\section{Gene arrangement}


One species was respectively selected from six families and one superfamily of the Heterodonta and its mitochondrial gene was compared 184 with the gene arrangement of $C$. attenuates (Fig. 2). It is found that the mitochondrial genes of the $S$. constricta and $C$. attenuates are exactly in the same order. For mitochondrial genes, species in different families have a large degree of rearrangement, while species in the same family 188 tend to have a small degree of rearrangement, and species in the same 189 genus even have almost no rearrangement ${ }^{[8,24]}$. Therefore, the 190 mitochondrial genes of the $S$. constricta and $C$. attenuates were not rearranged, further confirming the closer relationship between the two

192 species $^{[12]}$. The same phenomenon was also found in this comparison of 193 mitochondrial gene arrangement. There were only three gene blocks, 194 nad5-cob, rrnL-atp6-rrnS-cox3 and nad41-nad4, shared between $S$. 195 grandis and $C$. attenuates. However, the remaining five species from 196 different families shared fewer gene blocks, indicating a greater 197 rearrangement. This enormous gene rearrangement in bivalves is 198 associated with single-stranded coding, because double-stranded coding 199 tends to inhibit gene rearrangement compared to single-stranded coding $200 \quad[25]$.

201 Phylogenetic analysis

202 With the development of mitochondrial genome research, more and more 203 researchers conduct phylogenetic research on species through 
204 mitochondrial genes, but up to now, there has been relatively little 205 information about the mitochondrial genome of Heterodont ${ }^{[10,11]}$. In this 206 study, the phylogenetic tree was reconstructed through the amino acid 207 sequence of mitochondrial protein gene of heterodont bivalves (Fig. 3). 208 Two species of Lucinidae clustered into a single clade, and other species 209 clustered into a large clade containing three small clades, similar to 210 previous studies ${ }^{[11,26]}$. Paphia euglypta, Venerupis philippinarum, 211 Meritrix meretrix and Meritrix petechialis clustered together, supporting 212 their genetic relationship within Veneridae ${ }^{[26]}$. Moerella iridescens, 213 Sanguinolaria diphos, Sanguinolaria olivacea, Semele scaba and

214 Solecurtus divaricatus belonging to the superfamily Tellinoidea clustered 215 together, consistent with previous studies ${ }^{[22]}$. The new finding of this 216 study is that the $C$. attenuates had the closest relationship with $S$. 217 constricta, which further determines that $C$. attenuates and S. constricta 218 belong to the same family (Cultellidae) ${ }^{[12]}$. S. grandis and Solen strictus 219 had a closely relationship, with the $C$. attenuates and $S$. constricta being 220 the sister taxon. 
1. Boore JL (1999) Animal mitochondrial genomes. Nucleic Acids Res 27 :1767-1780. https ://doi.org/10.1093/nar/27.8.1767

2. Tatarenkov A, Avise JC (2007) Rapid concerted evolution in animal mitochondrial DNA. Proc R Soc B 274:1795-1798. https ://doi.org/10.10 98/rspb.2007.0169

3. Milbury CA, Gaffney PM (2005) Complete mitochondrial DNA sequence of the eastern oyster Crassostrea virginica. Mar Biotechnol 7:697-712. https ://doi.org/10.1007/s10126-005-0004-0

4. Aleix-Mata G, Gutiérrez J, Ruiz-Ruano FJ, Lorite P, Sánchez A (2020) The complete mitochondrial genome of Talpa aquitania (Talpidae; Insectivora), a mole species endemic to northern Spain and southern France. Mol Biol Rep 47:1-7.https://doi.org/10.1007/s11033-020-05296-8 (2019) Complete mitochondrial genome of Indian mithun, Bos frontalis and its phylogenetic implications. Mol Biol Rep 46: 2561-2566. https://doi.org/10.1007/s11033-019-04675-0

6. Hoffmann RJ, Boore JL, Brown WM (1992) A novel mitochondrial 239 genome organization for the blue mussel, Mytilus edulis. Genetics 131 :397-412. https ://doi.org/10.1016/1050-3862(92)90005-P 
commercial Crassostrea species. Mol Biol Rep 39: 999-1009.

244 https://doi.org/10.1007/s11033-011-0825-z

245 8. Xu KF, Kanno M, Yu H, Li Q, Kijima A (2011) Complete 246 mitochondrial DNA sequence and phylogenetic analysis of Zhikong 247 scallop Chlamys farreri (Bivalvia: Pectinidae). Mol Biol Rep $248 \quad 38$ :3067-3074. https://doi.org/10.1007/s11033-010-9974-8

249 9. He CB, Wang J, Gao XG, Song WT, Li HJ, Li YF, Liu WD, Su H 250 (2011) The complete mitochondrial genome of the hard clam Meretrix 251 meretrix. Mol Biol Rep 38 :3401-3409. https://doi.org/10.1007/s11033-01 $252 \quad 0-0449-8$

253 10. Yuan Y, Li Q, Kong LF, Yu H (2012) The complete mitochondrial 254 genome of the grand jackknife clam, Solen grandis (Bivalvia: Solenidae): 255 a novel gene order and unusual non-coding region. Mol Biol Rep 256 39 :1287-1292. https://doi.org/10.1007/s11033-011-0861-8

11. Taylor JD, Williams ST, Glover EA, Dyal P (2007) A molecular phylogeny of heterodont bivalves (Mollusca: Bivalvia: Heterodonta): new analyses of $18 \mathrm{~S}$ and 28S rRNA genes. Zool Scr 36: 587-606. https ://doi.org/10.1111/j.1463-6409.2007.00299.x

12. Yu ZZ, Li Q, Kong LF (2014) New insight into the phylogeny of Sinonovacula (Bivalvia: Solecurtidae) revealed by comprehensive DNA barcoding analyses of two mitochondrial genes. Mitochondrial DNA A 27:1554-1557. https://doi.org/10.3109/19401736.2014.953135 
265

266

267

268

269

270

271

272

273

274

275

276

277

278

279

280

281

282

283

284

285

286

13. Zheng RL, Li JL, Niu DH (2010) The complete DNA sequence of the mitochondrial genome of Sinonovacula constricta (Bivalvia:Solecurtidae). Acta Oceanol Sin 29: 88-92. https://doi.org/10.1007/s13131-010-0026-y

14. Yu RH, Wang YW, Zhang z, Ma PZ, Li LW, Sun CB (2019) Studies on artificial indoor breeding technique of Cultellus attenuatus. J Ocean U China 49:42-49. https://doi.org/10.16441/j.cnki.hdxb.20180171

15. Xu JT, Xu GC, Xu XH, Yan BL, Zhou HS (2013) Analysis of nutrition composition of edible parts of Cultellus attenuatus dunker. Food Science 34:263-267. https://doi.org/10.7506/spkx1002-6630-201317056

16. Milbury CA, Meritt DW, Newell RIE, Gaffney PM (2004) Mitochondrial DNA markers allow monitoring of oyster stock enhancement in the Chesapeake Bay. Mar Biol 145: 351-359. https://doi.org/10.1007/s00227-004-1312-z

17. Dutta N, Singh RK, Pathak A, Mohindra V, Mandal S, Kaur G, Lal KK (2020) Mitochondrial DNA markers reveal genetic connectivity among populations of Osteoglossiform fish Chitala chitala. Mol Biol Rep 47: 8579-8592. https://doi.org/10.1007/s11033-020-05901-w

18. Lowe TM, Eddy SR (1997) tRNAscan-SE: a program for improved detection of transfer RNA genes in genomic sequence. Nucleic acids Res 25:955-964. https://doi.org/10.1093/nar/25.5.955

19. Wyman SK, Jansen RK, Boore JL (2004) Automatic annotation of organellar genomes with DOGMA. Bioinformatics 20: 3252-3255. 
https://doi.org/10.1093/nar/25.5.955

20. Stothard P, Wishart DS (2005) Circular genome visualization and exploration using CGView. Bioinformatics 21: 537-539. https ://doi.org/1 0.1093/bioinformatics/bti054

21. Sudhir K, Glen S, Koichiro T (2016) MEGA7: Molecular evolutionary genetics analysis version 7.0 for bigger datasets. Mol Biol Evol 33: 1870-1874. https ://doi.org/10.1093/molbev/msw054

22. Yuan Y, Li Q, Yu H, Kong LF (2012) The complete mitochondrial genomes of six heterodont bivalves (Tellinoidea and Solenoidea): variable gene arrangements and phylogenetic implications. Plos One 7: e32353. https ://doi.org/10.1371/journal.pone.0032353

23. Xin ZZ, Yu L, Li CF, Zhang DZ, Jiang SH, Zhang HB, Zhou CL, Tang BP, Liu QN, Dai LS (2018) Mitochondrial genome of Argopecten irradians reveals higher-level phylogenetic relationships in Anisomyaria. Int J Biol Macromol 117:1089-1092. https ://doi.org/10.1016/j.ijbiomac. 2018.06.008

24. Zbawicka M, Burzyński A, Skibinski D, Wenne R (2010) Scottish Mytilus trossulus mussels retain ancestral mitochondrial DNA: Complete sequences of male and female mtDNA genomes. Gene 456: 45-53. https://doi.org/10.1016/j.gene.2010.02.009

25. Ren JF, Liu X, Jiang F, Guo XM, Liu B (2010) Unusual conservation of mitochondrial gene order in Crassostrea oysters: evidence for recent 
309 speciation in Asia. BMC Evol Biol 10: 394. https://doi.org/10.1186/1471$310 \quad 2148-10-394$

311 26. Mikkelsen PM, Bieler R, Kappner I, Rawlings TA (2006) Phylogeny

312 of Veneroidea (Mollusca: Bivalvia) based on morphology and molecules.

313 Zool J Linn Soc-Lond 148:439-521. https://doi.org/10.1111/j.1096-3642.2

$314 \quad 006.00262 . x$ 


\section{Declarations}

316 Funding

317 This work was supported by the grants from National Natural Science

318 Foundation of China (31172403), Science and Technology Innovation

319 Commission Project of Shenzhen, China (CXY201106270024A).

320 Consent for publication

321 All authors read and approved the final manuscript.

322 Availability of data and material

323 The mitochondrial genome sequence is available from gene Banks （MW653805）

325 Code availability

326 There is no relevant code

\section{Authors' contributions}

Ruihai Yu designed and supervised the project, and reviewed drafts of the

329 paper. Peizhen Ma provided technical assistance and collected the 330 samples. Chunhua Li provided technical assistance. Haikun Li wrote the 331 first draft of the manuscript. All authors commented on previous versions

332 of the manuscript before they read and approved the final manuscript.

334 Compliance with Ethical Standards

335 - Conflicts of interest/Competing interests

336 The authors declare that they have no conflict of interest. 


\section{-Ethics approval}

The present study was performed according to the standard operation procedures (SOPs) of the Guide for the Use of Experimental Animals of the Ocean University of China. All animal care and use procedures were approved by the Institutional Animal Care and Use Committee of Ocean University of China.

338 -Consent to participate

339 This article does not contain any studies with human 
Table 1 The organization of the mitochondrial genome of Cultellus

attenuates

\begin{tabular}{|c|c|c|c|c|c|c|}
\hline Feature & Position & Length (bp) & $\begin{array}{l}\text { Initiation } \\
\text { condon }\end{array}$ & Stop condon & Anticodon & $\begin{array}{l}\text { Intergenic } \\
\text { nucleotide }\end{array}$ \\
\hline $\operatorname{trnK}$ & $1-66$ & 66 & & & TTT & 64 \\
\hline $\operatorname{cox} 2$ & $131-968$ & 838 & ATG & $\mathrm{T}(\mathrm{AA})$ & & 74 \\
\hline $\operatorname{trn} Y$ & $1,043-1,106$ & 64 & & & GTA & 9 \\
\hline nad4l & $1,116-1,406$ & 291 & ATG & TAA & & -1 \\
\hline $\operatorname{trnG}$ & $1,406-1,472$ & 67 & & & TCC & 8 \\
\hline $\operatorname{trnP}$ & $1,481-1,546$ & 66 & & & TGG & 103 \\
\hline nad4 & $1,650-3,020$ & 1371 & ATT & TAA & & 13 \\
\hline $\operatorname{trnH}$ & $3,034-3,097$ & 64 & & & GTG & 2 \\
\hline $\operatorname{trn} W$ & $3,100-3,166$ & 67 & & & TCA & 11 \\
\hline $\operatorname{trnR}$ & $3,178-3,242$ & 65 & & & TCG & 27 \\
\hline $\operatorname{trnE}$ & $3,270-3,334$ & 65 & & & TTC & -6 \\
\hline $\operatorname{trnS} 2$ & $3,329-3,391$ & 63 & & & TGA & \\
\hline $\operatorname{nad} 3$ & $3,392-3,757$ & 366 & ATG & TAG & & -1 \\
\hline $\operatorname{trnT}$ & $3,757-3,823$ & 67 & & & TGT & \\
\hline $\operatorname{trnI}$ & $3,824-3,890$ & 67 & & & GAT & 5 \\
\hline $\operatorname{trnD}$ & $3,896-3,962$ & 67 & & & GTC & \\
\hline $\operatorname{trnQ}$ & $3,963-4,029$ & 67 & & & TTG & 25 \\
\hline $\operatorname{trnC}$ & $4,055-4,120$ & 66 & & & GCA & 25 \\
\hline $\operatorname{trn} A$ & $4,146-4,210$ & 65 & & & TGC & 28 \\
\hline $\operatorname{trnF}$ & $4,239-4,302$ & 64 & & & GAA & 149 \\
\hline $\operatorname{cox} 1$ & $4,452-6,140$ & 1689 & ATT & TAA & & 11 \\
\hline $\operatorname{trnL2}$ & $6,152-6,218$ & 67 & & & TAA & -3 \\
\hline nad1 & $6,216-7,145$ & 930 & ATA & TAG & & 2 \\
\hline $\operatorname{trnL1}$ & $7,148-7,214$ & 67 & & & TAG & 10 \\
\hline $\operatorname{trn} V$ & $7,225-7,289$ & 65 & & & TAC & 12 \\
\hline $\operatorname{trnN}$ & $7,302-7,367$ & 66 & & & GTT & \\
\hline nad5 & $7,368-9,128$ & 1761 & ATT & TAG & & 38 \\
\hline cob & $9,167-10,312$ & 1146 & ATG & TAG & & 7 \\
\hline nad6 & $10,320-10,850$ & 531 & ATG & TAG & & \\
\hline $\mathrm{rrnL}$ & $10,851-12,087$ & 1237 & & & & \\
\hline atp6 & $12,088-12,786$ & 699 & ATG & TAA & & 15 \\
\hline $\operatorname{trnM}$ & $12,802-12,867$ & 66 & & & CAT & 100 \\
\hline $\mathrm{rrnS}$ & $12,968-13,794$ & 827 & & & & \\
\hline $\operatorname{cox} 3$ & $13,795-14,583$ & 789 & ATG & TAG & & 6 \\
\hline $\operatorname{trnS} 1$ & $14,590-14,656$ & 67 & & & TCT & \\
\hline $\operatorname{nad} 2$ & $14,657-15,715$ & 1059 & ATG & TAA & & 1173 \\
\hline
\end{tabular}


Table 2 The base composition of mitochondrial genome, protein coding genes and ribosomal RNA genes

\begin{tabular}{lllllllll}
\hline Region & A\% & C\% & G\% & T\% & A+T\% & G+C\% & AT skew & GC skew \\
\hline Whole genome & 23.54 & 10.61 & 22.94 & 42.91 & 66.46 & 33.54 & -0.291 & 0.368 \\
cox2 & 25.89 & 10.26 & 26.13 & 37.71 & 63.60 & 36.40 & -0.186 & 0.436 \\
nad41 & 21.65 & 7.56 & 24.40 & 46.39 & 68.04 & 31.96 & -0.364 & 0.527 \\
nad4 & 18.75 & 8.17 & 24.07 & 49.02 & 67.76 & 32.24 & -0.447 & 0.493 \\
nad3 & 18.85 & 8.20 & 22.40 & 50.55 & 69.40 & 30.60 & -0.457 & 0.464 \\
cox1 & 20.25 & 12.97 & 23.92 & 42.87 & 63.11 & 36.89 & -0.358 & 0.297 \\
nad1 & 19.14 & 9.57 & 24.73 & 46.56 & 65.70 & 34.30 & -0.417 & 0.442 \\
nad5 & 18.57 & 10.39 & 23.74 & 47.30 & 65.87 & 34.13 & -0.436 & 0.391 \\
cob & 20.68 & 12.13 & 21.38 & 45.81 & 66.49 & 33.51 & -0.378 & 0.276 \\
nad6 & 20.90 & 8.10 & 23.35 & 47.65 & 68.55 & 31.45 & -0.390 & 0.485 \\
rrnL & 32.66 & 10.83 & 19.48 & 37.03 & 69.68 & 30.32 & -0.063 & 0.285 \\
atp6 & 20.89 & 10.87 & 21.17 & 47.07 & 67.95 & 32.05 & -0.385 & 0.321 \\
rrnS & 35.07 & 13.30 & 20.31 & 31.32 & 66.38 & 33.62 & 0.056 & 0.209 \\
cox3 & 21.04 & 12.67 & 23.70 & 42.59 & 63.62 & 36.38 & -0.339 & 0.303 \\
nad2 & 20.68 & 10.48 & 23.70 & 45.14 & 65.82 & 34.18 & -0.372 & 0.387 \\
\hline
\end{tabular}


Table 3 The comparison of non-coding regions (NCR) within the eight mitochondrial genomes of the Heterodonta

\begin{tabular}{|c|c|c|c|c|c|c|}
\hline \multirow{2}{*}{ Species } & \multirow{2}{*}{$\begin{array}{r}\text { No. of } \\
\text { NCR } \\
\end{array}$} & \multirow{2}{*}{ Total length (bp) } & \multirow{2}{*}{$\begin{array}{l}\text { Proportion of the } \\
\text { mt genome }(\%)\end{array}$} & \multicolumn{3}{|c|}{ Largest NCR } \\
\hline & & & & Lenth (bp) & $\mathrm{A}+\mathrm{T} \%$ & Location \\
\hline Paphia euglypta & 28 & 2431 & 13.04 & 1774 & 65.80 & nad4L - trnI \\
\hline Acanthocardia tuberculata & 24 & 1751 & 9.60 & 1103 & 59.11 & trnaM - trnaH \\
\hline Hiatella arctica & 30 & 2558 & 14.05 & 614 & 66.10 & trnaA - atp8 \\
\hline Solen grandis & 27 & 1699 & 10.12 & 435 & 66.44 & trnaN - trnaP \\
\hline Sinonovacula constricta & 25 & 2134 & 12.39 & 1492 & 66.89 & $\operatorname{nad} 2-\operatorname{trnK}$ \\
\hline Cultellus attenuates & 24 & 1917 & 11.35 & 1173 & 68.24 & $\operatorname{nad} 2-\operatorname{trnK}$ \\
\hline Lucinella divaricata & 31 & 3825 & 20.20 & 1050 & 69.24 & trnaC - trnaL2 \\
\hline Solecurtus divaricatus & 22 & 1160 & 6.93 & 775 & 65.81 & $\operatorname{rrnS}-\operatorname{trnM}$ \\
\hline
\end{tabular}




\section{Figure legend}

Fig.1 The complete genome circle of mitochondria in Cultellus attenuates. From inside to outside, the first circle represents the scale; the second circle represents the GC skew; the third circle represents GC content; the fourth and fifth circle represent the arrangement of protein-coding genes, tRNA genes and rRNA genes on the genome

Fig. 2 The linear representation of the mitochondrial gene arrangement in eight species of the Heterodonta. The bars indicate identical gene blocks Fig.3 The phylogenetic trees derived from Neighbour-Joining (NJ) of concatenated amino acid sequences of 12 protein-coding genes 
341

342 


\section{Figures}

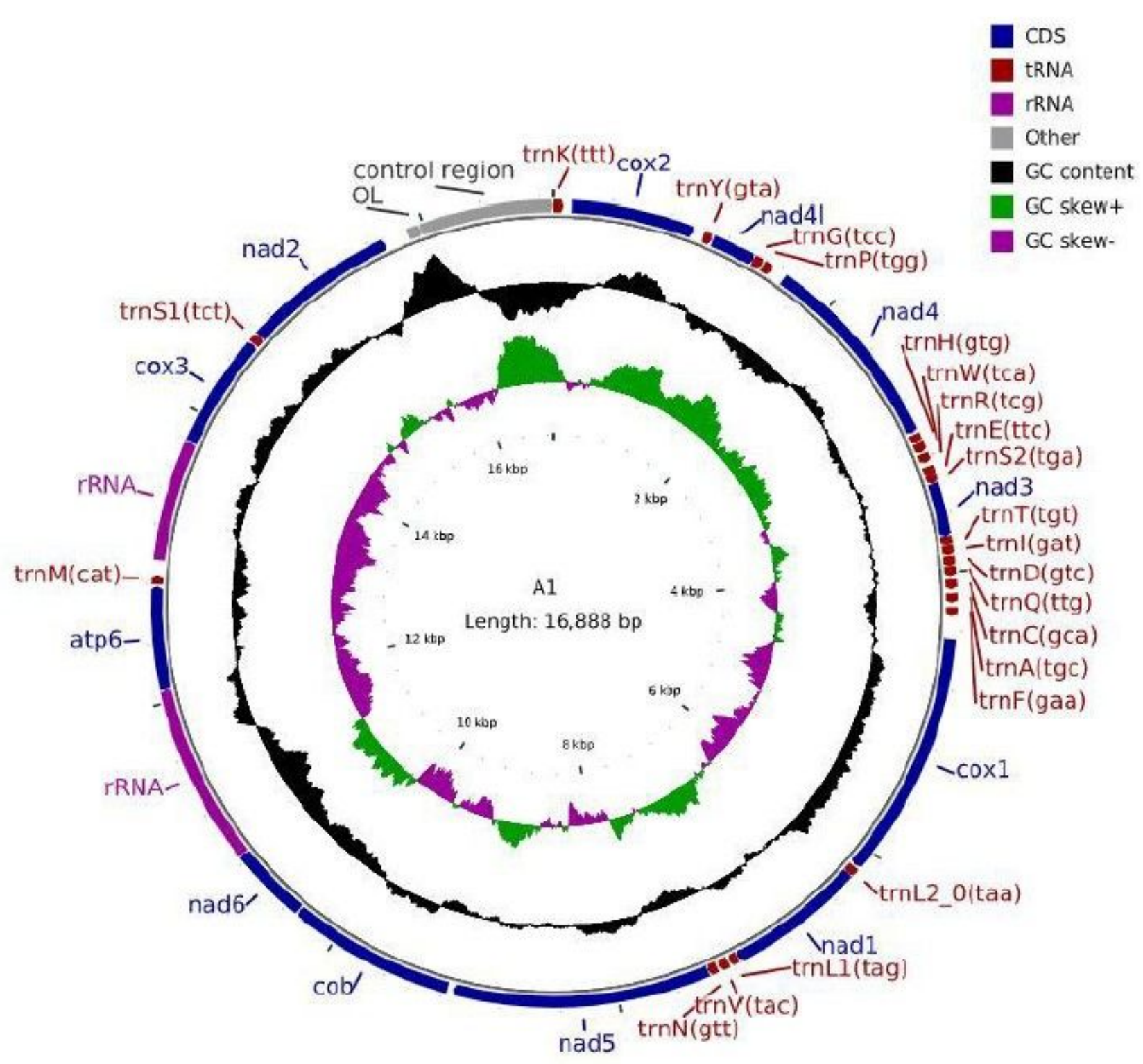

Figure 1

The complete genome circle of mitochondria in Cultellus attenuates. From inside to outside, the first circle represents the scale; the second circle represents the GC skew; the third circle represents GC content; the fourth and fifth circle represent the arrangement of protein-coding genes, tRNA genes and rRNA genes on the genome 


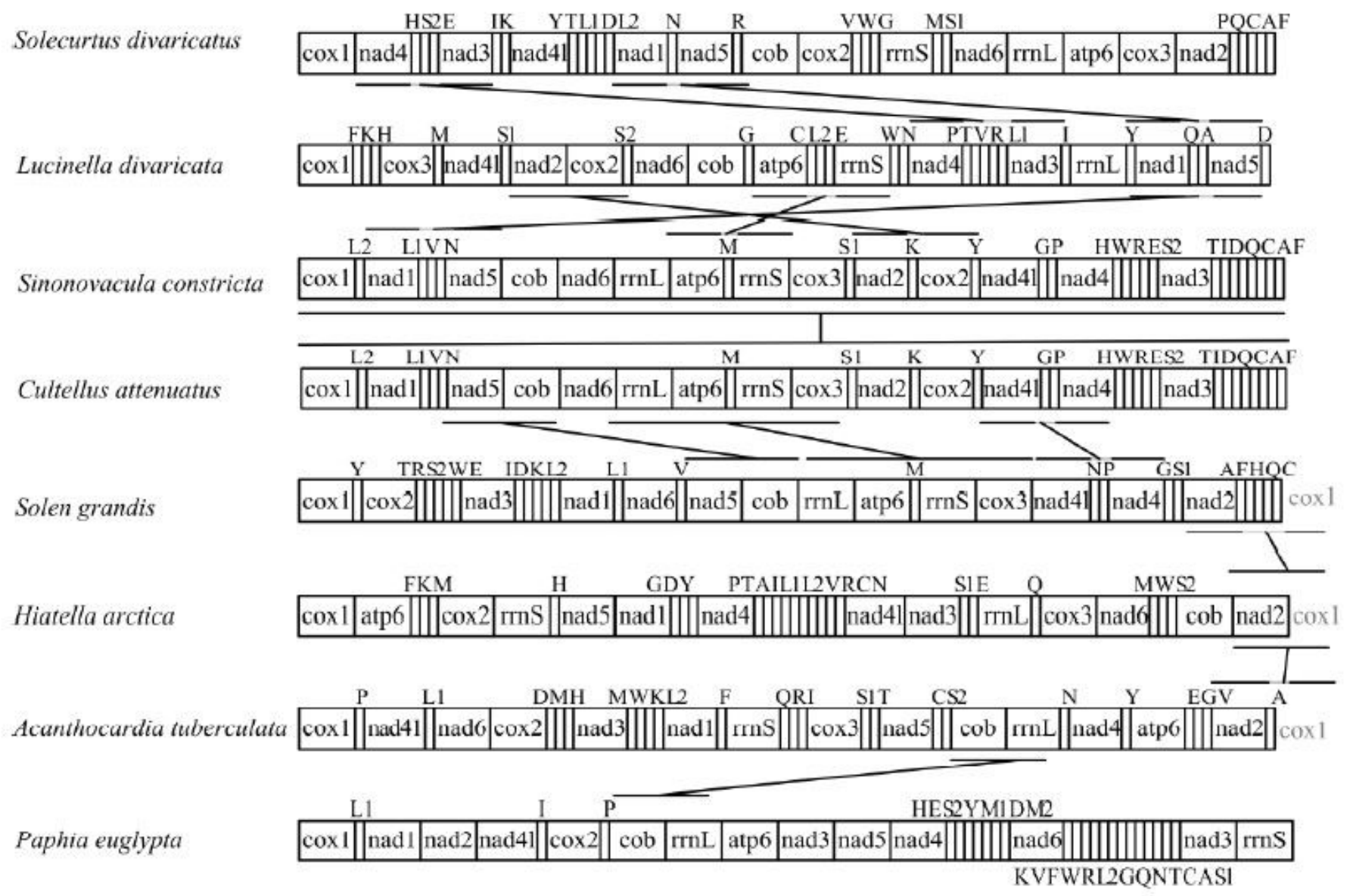

\section{Figure 2}

The linear representation of the mitochondrial gene arrangement in eight species of the heterodonta. The bars indicate identical gene blocks 


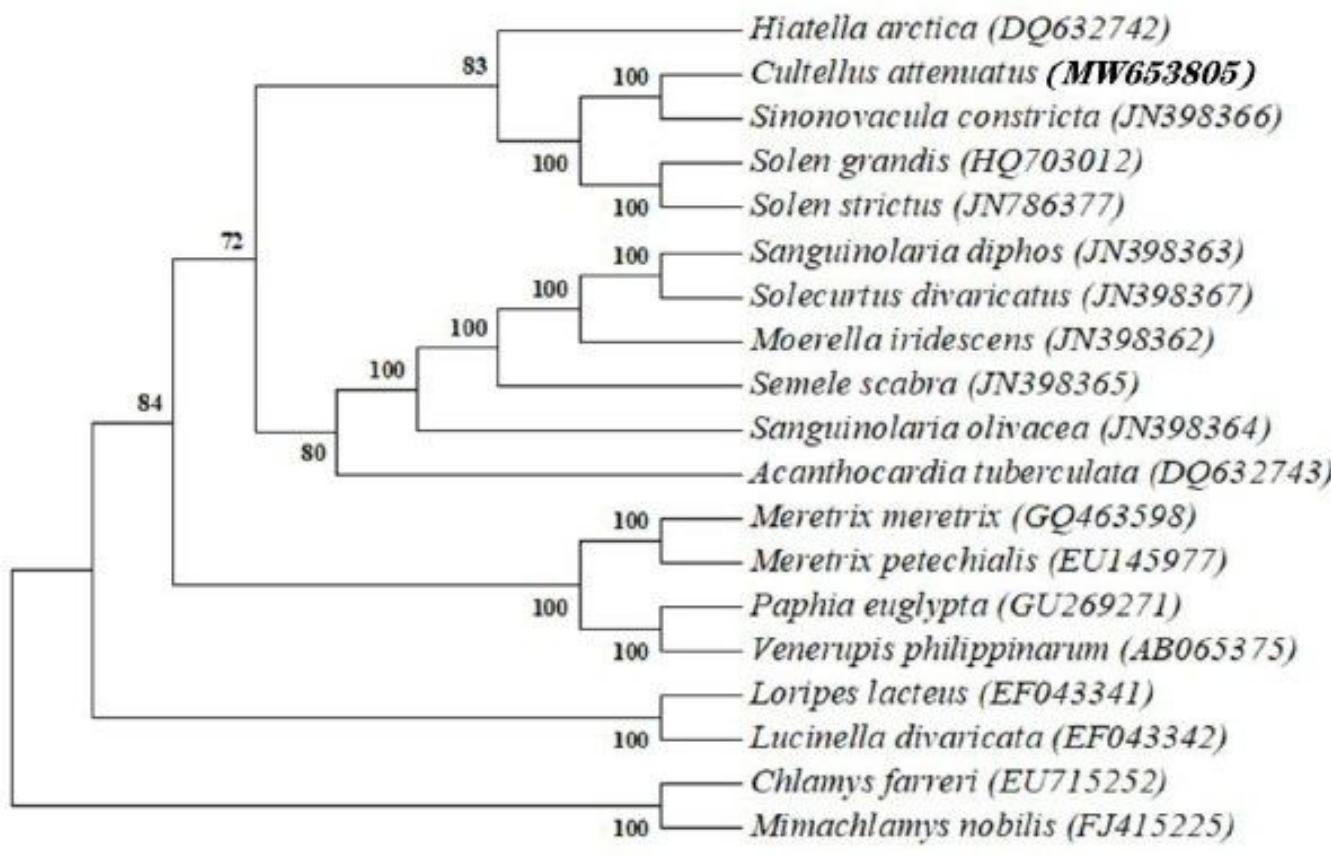

$\mid$ Hiatellidae
$\mid$ Cultellidae
$\mid$ Solenoidae
$\mid$ Psammobiidae
$\mid$ Solecurtidae
$\mid$ Tellininae
| Semelidae
| Psammobiidae
$\mid$ Cardiidae
$\mid$ Veneridae

Lucinidae
Outproup

\section{Figure 3}

The phylogenetic trees derived from Neighbour-Joining $(\mathrm{NJ})$ of concatenated amino acid sequences of 12 protein-coding genes 